\title{
The Teaching and Learning Status of Chemical Safety in Chinese Universities and Reform Suggestions on It
}

\author{
Zhiqiang Zhou, Li Guo* \\ College of Chemistry, Chemical Engineering and Resource Utilization, Northeast Forestry University, Harbin, China \\ Email: *guoli_nefu@nefu.edu.cn
}

How to cite this paper: Zhou, Z. Q., \& Guo, L. (2019). The Teaching and Learning Status of Chemical Safety in Chinese Universities and Reform Suggestions on It. Creative Education, 10, 2132-2136. https://doi.org/10.4236/ce.2019.1010154

Received: September 22, 2019

Accepted: October 11, 2019

Published: October 14, 2019

Copyright $\odot 2019$ by author(s) and Scientific Research Publishing Inc. This work is licensed under the Creative Commons Attribution International License (CC BY 4.0).

http://creativecommons.org/licenses/by/4.0/

\section{c) (i) Open Access}

\begin{abstract}
Chinese universities began late in setting up the course of Chemical Safety for cultivating qualified chemical engineers. What is more, this course is still based on traditional classroom teaching, while creative educational reform is lacked. The humdrum and passive listening makes the fact that students' interest and initiative in leaning are not high, and their consciousness of chemical safety is not strong. Students are currently far away from understanding, mastering, and applying the professional knowledge in this course. The current teaching and learning effect leaves much to be desired. In this work, we report the current teaching and learning status of this course in Chinese universities, and bring up some suggestions on teaching and learning reform.
\end{abstract}

\section{Keywords}

Chemical Safety, Teaching and Learning Reform, Chinese Universities

\section{Introduction}

Chemical industry is a trade of high risks with diversified and complicated risk factors. Chemical accidents occur frequently, often cause major loss of life and property. Along with the development and application of new technologies, the process of chemical production becomes more and more complicated, and the degree of automation becomes higher and higher. At the same time, the accompanying problems in chemical safety become increasingly acute (Yao, Wang, \& Zhang, 2011). It is found that most of the chemical accidents were due to the weak consciousness of chemical safety of chemical engineers and workers and the lack of corresponding professional knowledge ( $\mathrm{Du}$, Chen, Lin, Zhao, \& Zhang, 2015). Therefore, improving chemical safety must be supported by quali- 
fied chemical talents, and the course of Chemical Safety is essential for related majors.

Chemical Safety is a course with typical industry background. It is a branch of science and technology that, in order to prevent and control chemical accidents, applies safety science, safety technology, and safety management to the process of chemical production and studies the causes and laws of accidents (Huang, Zhuang, Wu, \& Rao, 2017). Therefore, it is an interdisciplinary course that involves a wide range of contents, diversified knowledge points, and strong engineering practice (Liao, Wei, Lu, Su, Jiang, \& Yang, 2016; Hu, Zheng, \& Weng, 2016). The teaching and learning of it are somewhat difficult and require active reform exploration and practice.

In this work, we present the role of Chemical Safety for cultivating qualified chemical engineers, analyze the features of this course, and evaluate the current teaching and learning status of this course in Chinese universities. Based on dispassionately analysis and closely against the current situation of this course, we bring up some suggestions on teaching and learning reform. The reform suggestions may provide approaches for educators to try teaching and learning reform on this course.

\section{Current Teaching and Learning Status of Chemical Safety in Chinese Universities}

In higher education concerning chemical engineering, Chinese universities were more focused on the teaching and learning of production technology and processes, while less attention was paid to the teaching and learning of chemical safety, which makes the fact that students' consciousness of chemical safety is weak and the corresponding knowledge is lacked. And now, Chinese universities have recognized this problem and are rushing to set up the course of Chemical Safety in relevant programs.

The class hours for this course are relatively less (16 - 32 class hours are most common). It is difficult both for teachers to teach, and for students to understand so many interdisciplinary knowledge points in the limited class hours. What is more, this course is carried out mainly based on the traditional "cramming" styled classroom teaching, while the practical training is poor. The students are just passive listeners and never try to find problems, raise problems, analyze problems and solve problems. This mode of teaching leads to the fact that students' interest and initiative in leaning are not high, their consciousness of chemical safety is not strong, and they are far away from understanding, mastering, and applying the professional knowledge. This phenomenon has aroused great concern from leaders of the former State Administration of Work Safety, P. R. China and the Ministry of Education, P. R. China. On November 22, 2016, the former State Administration of Work Safety united the Ministry of Education to jointly order that the course concerning progress safety in chemical engineering must be set up as a compulsory course in related majors in Chinese 
universities, and related teaching and learning reforms on this course should be encouraged.

\section{Suggestions on Teaching and Learning Reform of Chemical Safety in Chinese Universities}

\subsection{Guiding Thoughts}

The reform should start from updating of teaching philosophy. The traditional teaching model of "teacher just teaches while students just listen" should be modified; students' dominant role in learning should be established and enhanced; special attention should be paid to the cultivation of students' quality of "being diligent in thinking, being dare to doubt and innovate"; and students' ability and habit of continuous self-learning should be cultivated. On the basis of teaching outlined knowledge, teachers shall inspire students to initiatively learn, expand and master knowledge, guide students to internalize and strengthen their learned knowledge through the procedure of finding problems, raising problems, analyzing problems and solving problems in actual cases, and thus cultivate students' ability of using learned knowledge to solve practical problems. In this way, students may have the ability of continuous self-learning and ability of solving practical problems through self-learning. It may be described by a Chinese saying of "it is always better to teach a person to fish than just to give him some fish".

\subsection{Key Points to Do in the Reform}

In the reform, students' practical training in actual cases shall be strengthened, and their ability of continuous self-learning and ability of solving practical problems shall be cultivated. Teachers shall outline and teach the diversified interdisciplinary knowledge points in a mode of "simplification" and bury a foreshadowing, and teachers shall inspire and guide students to initiatively widen their knowledge scope, to learn what is useful but not covered in the limited class hours. As for the outlined knowledge of each chapter, teachers shall direct students to find problems, raise problems, analyze problems and solve problems in actual cases. Teachers shall inspire students in meticulous thinking, scientific analyzing, and solving practical problems.

\subsection{Key Issues to Be Addressed in the Reform}

Key issues are difficult ones. For the reform to proceeds smoothly, teachers' vigorous innovation, meticulous design and powerful execution are essential. The key issues include: how to effectively enhance students' dominant role in learning; how to effectively involve students into the dynamic process of finding problems, raising problems, analyzing problems, and solving problems; how to outline and teach the essences no more and no less to the students in classroom and bury a foreshadowing; how to guide students to expand their knowledge, to acquire knowledge that is not covered in classroom teaching, and to cultivate the 
ability and habit of continuous leaning.

\subsection{Expected Goals of Reform}

The students shall turn to be initiative in learning the course. They shall internalize and strengthen the learned knowledge through the procedure of finding problems, raising problems, analyzing problems, and solving problems in actual cases. They shall preliminarily have cultivated the habit and ability of expanding knowledge by initiative self-learning, and ability of solving practical problems. The classroom teaching shall get effective extension and functions as "throwing out a minnow to catch a whale".

\subsection{Reform of Course Assessment}

Traditional assessment of this course in most universities comprises two parts. The first is the finial written examination generally accounting for $80 \%$ of the total score. The second is the usual-time mark generally accounting for $20 \%$, which is commonly composed of attendance (most important), classroom performance, and homework. As for this course of Chemical Safety, we cannot expect teachers to teach and students to learn \& master all the diversified interdisciplinary knowledge points in the limited classroom teaching. What is most important is to inspire students' initiative and cultivate their potential ability. In the reform, the action of expanding knowledge by self-learning and the ability cultivation therein should be taken as the main basis for the usual-time mark. The percentage of the usual-time mark may be increased to $40 \%, 50 \%$, or even $60 \%$ for example, while that of the final written examination may be decreased to $60 \%, 50 \%$, or even $40 \%$. In this way, the students' initiative in learning may be inspired.

\section{Conclusion}

Chemical Safety is an essential course for cultivating qualified chemical engineers, and it is an interdisciplinary course that involves a wide range of contents, diversified knowledge points, and strong engineering practice. The teaching and learning of it are somewhat difficult and require active reform exploration and practice. The current teaching \& learning model and the effect need to be reformed and improved urgently. Teaching and learning reform is always on the road. It needs educators' active exploration, daring innovation, and warm communication.

\section{Acknowledgements}

This work was financially supported by the Higher Education Teaching Reform Project in Heilongjiang Province (SJGY20170129, SJGY20180021) and the Fundamental Research Funds for the Central Universities (2572015CB28).

\section{Conflicts of Interest}

The authors declare no conflicts of interest regarding the publication of this paper. 


\section{References}

Du, Y., Chen, D. J., Lin, Z. B., Zhao, J. S., \& Zhang, C. (2015). Construction and Practice of Safety Education System. Experimental Technology and Management, 32, 231-236.

Hu, J., Zheng, C. Z., \& Weng J. S. (2016). Discussion on Course Teaching of Chemical Safety and Environment Protection. Guangzhou Chemical Industry, 45, 181-182.

Huang, Y., Zhuang, Y. L., Wu, S. K., \& Rao, J. B. (2017). Teaching Reform of Chemical Safety Engineering Based on Excellence Plan. Higher Education in Chemical Engineering, 1, 50-52.

Liao, C. J., Wei, X. D., Lu, L. L., Su, L., Jiang, J. L., \& Yang, M. (2016). Analysis on the Chemical Engineering Safety Direction of Safety Engineering in Colleges and Universities. Higher Education in Chemical Engineering, 3, 44-47.

Yao, G. B., Wang, Y. Q., \& Zhang, X. H. (2011). Research on Teaching Innovation of Chemical Safety \& Environment. Guangzhou Chemical Industry, 39, 140-142. 